\title{
Analisis portofolio Optimum Saham Syariah Menggunakan Stochastic Dominance
}

\author{
Eruit Kuswandanu \\ Program Studi Matematika Fakultas Sains dan Teknologi, UIN Sunan Kalijaga, Jl. Marsda Adisucipto \\ No. 1 Yogyakarta, Indonesia \\ Korespondensi; Email: eruit.k@gmail.com
}

\begin{abstract}
Abstrak
Hal terpenting yang diperhatikan oleh seorang investor adalah bagaimana investasi dapat menghasilkan return optimal pada tingkat resiko yang minimal, sehingga untuk mengetahui hal tersebut investor dapat melakukan diversifikasi. Diversifikasi dapat diwujudkan dengan cara mengkombinasikan berbagai pilihan saham dalam investasi (membentuk portofolio saham optimal). Salah satu teknik analisa portofolio optimal adalah menggunakan metode stochastic dominance, dimana metode ini tidak mensyaratkan distribusi dari return investasi harus bersifat normal. Penelitian ini menggunakan studi kasus pada saham syariah Jakarta Islamic Index (JII) yang tergabung dalam Bursa Efek Indonesia (BEI) pada periode Januari 2012 - Desember 2014. Hasil penelitian menunjukan terdapat 6 saham yang memiliki dominasi, diantaranya adalah ICBP, INDF, JSMR, PGAS, WIKA, SMGR. Proporsi tertinggi dimiliki oleh saham JSMR dan PGAS sebesar 25\%, proporsi saham WIKA dan ICBP sebesar 18,75\%, kemudian proporsi terendah adalah saham INDF dan SMGR sebesar 6,25\%. Besar tingkat pengembalian yang diharapkan dalam portofolio optimal adalah $2,845 \%$.
\end{abstract}

Kata Kunci: Portofolio O ptimal; Saham Syariah; Stochastic dominance

\begin{abstract}
The most important thing to be considered by an investor is how the investment can generate optimal returns at minimal risk level, so as to know that investors can diversify. Diversification can be realized by combining various stock selection in the investment (to form an optimal stock portfolio). One technique is the optimal portfolio analysis using the method of stochastic dominance, where this method does not require the distribution of investment returns should be normal. This study uses a case study in Islamic stocks Jakarta Islamic Index (JII) incorporated in the Indonesia Stock Exchange (BEI) in the period January 2012 - December 2014. The results showed there are six stocks that have dominance, including the ICBP, INDF, JSMR, PGAS, WIKA, SMGR. The highest proportion of shares owned by JSMR and PGAS by $25 \%$, the proportion of WIKA and ICBP share of $18.75 \%$, and the lowest proportion is INDF and SMGR shares of $6.25 \%$. Large expected returns in the optimal portfolio is $2.845 \%$.
\end{abstract}

Keywords: O ptimum Portfolio; Islamic stocks; Stochastic dominance

\section{Pendahuluan}

Investasi secara umum diartikan sebagai keputusan mengeluarkan dana pada saat sekarang ini untuk membeli aktiva riil atau aktiva keuangan dengan tujuan untuk mendapatkan penghasilan yang lebih besar dimasa yang akan datang. Investasi selalu berhadapan dengan risiko ketidakpastian, karena pengeluaran dilakukan pada saat sekarang, sedangkan manfaatnya baru akan diterima dalam waktu yang akan datang (Haming, 2010).

Sebuah keputusan investasi dikatakan optimal jika pengaturan waktu konsumsi tersebut dapat memaksimumkan ekspetasi utilitas (expected utility). Untuk memaksimumkan utilitas seseorang hanya akan melakukan investasi jika ekspetasi manfaat dari penundaan konsumsi lebih besar dibandingkan dengan jika uang tersebut dibelanjakan sekarang. Namun yang menjadi masalah adalah bahwa 
ekspetasi manfaat tersebut nilainya tidak pasti (Arifin, 2007, p.21). Dalam keadaan seperti itu para pemodal hanya akan mengharapkan untuk memperoleh tingkat keuntungan tertentu.

Model utilitas yang diharapkan menggunakan asumsi sikap pemodal terhadap risiko. Sikap-sikap tersebut dikelompokan menjadi tiga, yaitu sikap yang risk averse (tidak menyukai risiko), risk neutral (netral terhadap risiko), dan risk seeker (menyukai risiko). Pada umumnya pemodal bersikap risk averse (tidak menyukai risiko) berarti bahwa mereka mengharapkan kompensasi tingkat keuntungan yang makin besar jika mereka harus menanggung risiko yang makin besar untuk tambahan unit risiko yang sama. Dengan menggunakan asumsi risk averse, portofolio yang dipilih adalah portofolio yang merupakan titik singgung antara efficient frontier dengan kurva indifference pemodal. Akan tetapi pendekatan tersebut mempunyai kesulitan dalam operasionalisasinya, meskipun telah diperkenalkan bagaimana menggambarkan kurva indifference pemodal. Kesulitan tersebut adalah bagaimana merumuskan kurva indifference para pemodal. Oleh karena itu kemudian dikembangkan beberapa cara, salah satunya adalah stochastic dominance (Husnan, 2009, p.152).

Stochastic Dominance merupakan suatu teknik untuk memilih investasi yang berisiko tanpa harus menggunakan distribusi normal untuk tingkat keuntungan. Stochastic dominance diterapkan untuk mengatasi masalah mengenai pemilihan dan evaluasi dari investasi saham maupun portofolio, karena lemahnya teori ekonomi dalam memberikan prediksi atau gambaran masa depan mengenai preferensi investor dan distribusi keuangan (Post, 2003, p.1906). Stochastic dominance adalah generalisasi dari teori utilitas yang menghilangkan kebutuhan untuk secara eksplisit menentukan fungsi utilitas perusahaan. Sebaliknya, pernyataan matematika umum tentang preferensi kekayaan, risk aversion, dII digunakan untuk mengembangkan aturan keputusan yang optimal untuk memilih antara alternatif investasi (Heyer, 2001). Stochastic dominance menggunakan tiga asumsi yang semakin kuat tentang perilaku para pemodal, asumsi-asumsi tersebut disebut sebagai first order stochastic dominance, second order stochastic dominance dan third order stochastic dominance. First order stochastic dominance menyatakan bahwa pemodal lebih menyukai yang banyak daripada yang sedikit, second order stochastic dominance menyatakan bahwa pemodal bersikap risk averse atau tidak menyukai risiko dan third order stochastic dominance menyatakan bahwa pemodal mempunyai sikap ruin averse, asumsi yang ketiga ini berarti bahwa dengan meningkatnya kekayaan para pemodal, mereka akan menginvestasikan yang lebih banyak pada kesempatan investasi yang berisiko. (Husnan, 2009, p.149).

Untuk itu, penelitian ini akan menganalisis pembentukan portofolio optimal investasi saham menggunakan metode stochastic dominance pada studi kasus Jakarta Islamic Index (JII).

\section{Landasan Teori}

\section{Investasi}

Investasi pada hakekatnya merupakan penempatan sejumlah dana pada saat ini dengan harapan untuk memperoleh keuntungan di masa mendatang (Halim, 2003, p.2). Ada dua kategori investasi yang selama ini kita kenal, yaitu (a) real assets (aset riil), yakni: investasi yang dilakukan pada aktiva yang berujud seperti gedung, kendaraan, mesin dan sebagainya, (b) financial assets (aset keuangan), yakni: investasi yang dilakukan pada dokumen (surat-surat) klaim tidak langsung pemiliknya terhadap aset riil pihak yang menerbitkan dokumen tersebut (Suhartono dan Qudsi, 2009. P.28).

Proses investasi menunjukan bagaimana pemodal seharusnya melakukan investasi dalam sekuritas; yaitu sekuritas apa yang akan dipilih, seberapa banyak investasi tersebut dan kapan investasi tersebut akan dilakukan. Untuk mengambil keputusan tersebut diperlukan langkah-langkah sebagai berikut (Husnan, 2009, p. 48):

1. Menentukan kebijakan investasi

Pemodal perlu menentukan apa tujuan investasinya, dan berapa banyak investasi tersebut akan dilakukan. Karena ada hubungan yang positif antara risiko dan keuntungan investasi, maka pemodal tidak bisa mengatakan bahwa tujuan investasinya adalah untuk mendapatkan keuntungan yang sebesar-besarnya. la harus menyadari bahwa ada kemungkinan untuk menderita rugi. Jadi tujuan investasi harus dinyatakan baik dalam keuntungan maupun risiko. 


\section{Analisis Sekuritas}

Tahap ini berarti melakukan analisis terhadap individual (atau sekelompok) sekuritas. Ada dua filosofi dalam melakukan analisis sekuritas. Pertama adalah mereka yang berpendapat bahwa ada sekuritas yang mispriced (harganya salah, mungkin terlalu tinggi, mungkin terlalu rendah), dan analis dapat mendeteksi sekuritas-sekuritas tersebut. Ada berbagai cara untuk melakukan analisis ini, tetapi pada garis besarnya cara-cara tersebut dapat dikelompokan menjadi dua, yaitu analisis teknikal dan analisis fundamental. Analisis teknikal menggunakan data (perubahan) harga di masa yang lalu sebagai upaya untuk memperkirakan harga sekuritas di masa yang akan datang. Analisis fundamental berupaya mengidentifikasikan prospek perusahaan (lewat analisis terhadap faktor-faktor yang mempengaruhinya) untuk bisa memperkirakan harga saham di masa yang akan datang. Kedua adalah mereka yang berpendapat bahwa harga sekuritas adalah wajar, kalaupun ada sekuritas yang mispriced, analis tidak mampu untuk mendeteksinya.

3. Pembentukan Portofolio

Tahap ini menyangkut identifikasi sekuritas-sekuritas mana yang akan dipilih, dan berapa proporsi dana yang akan ditanamkan pada masing-masing sekuritas tersebut.

4. Melakukan revisi portofolio

Tahap ini merupakan pengulangan terhadap tiga tahap sebelumnya, dengan maksud kalau perlu melakukan perubahan terhadap portofolio yang telah dimiliki.

5. Evaluasi kinerja portofolio

Dalam tahap ini pemodal melakukan penilaian terhadap kinerja (performance) portofolio, baik dalam aspek tingkat keuntungan yang diperoleh maupun risiko yang ditanggung.

\section{Pasar Modal Syariah}

Definisi pasar modal sesuai dengan Undang-undang Nomor 8 Tahun 1995 tentang Pasar Modal (UUPM) adalah kegiatan yang bersangkutan dengan Penawaran Umum dan perdagangan Efek, Perusahaan Publik yang berkaitan dengan Efek yang diterbitkannya, serta lembaga dan profesi yang berkaitan dengan efek. Berdasarkan definisi tersebut _erminology pasar modal syariah dapat diartikan sebagai kegiatan dalam pasar modal sebagaimana yang diatur dalam UUPM yang tidak bertentangan dengan prinsip syariah.

Tonggak perkembangan pasar modal syariah di Indonesia diawali dengan dikeluarkannya Jakarta Islamic Index (JII) pada tanggal 3 Juli 2000. Jakarta Islamic Index (JII) adalah salah satu indeks saham yang ada di Indonesia yang menghitung indeks harga rata-rata saham untuk jenis saham-saham yang memenuhi kriteria syariah. Jakarta Islamic Index (JII) terdiri dari 30 saham yang dipilih dari sahamsaham yang sesuai dengan syariah Islam, dan anggota saham JII selalu diperbarui selama 3 bulan sekali. Seperti pasar modal pada umumnya, pasar modal syariah memberikan sarana investasi dengan berbagai tawaran produk yang dapat dipilih oleh masyarakat sebagai investor seperti saham syariah, obligasi syariah (sukuk), efek beragunan asset syariah, dan reksadana syariah.

\section{Sifat Fungsi Utilitas}

Dalam menentukan fungsi utilitas, harus memiliki ukuran yang secara khusus mengidentifikasi setiap outcome bisnis, ukuran tersebut biasanya adalah beberapa ukuran profitabilitas atau terminal wealth, dan fungsi yang memetakan setiap outcome bisnis untuk utilitas yang sesuai. Konvensi utilitas adalah merupakan ukuran ordinal, dengan kata lain utilitas dapat digunakan untuk menentukan rank ordering outcome, tetapi tidak dapat digunakan untuk menentukan sejauh mana yang lebih disukai daripada yang lain. Transformasi linear dari fungsi utilitas masih akan menghasilkan urutan peringkat yang sama pada alternatif investasi. Akan tetapi, jarang diketahui sebuah priori apakah outcome akan diperoleh dari berbagai alternatif investasi. Sebaliknya, terminal wealth diperkirakan memiliki beberapa distribusi yang bervariasi tergantung pada alternatif investasi yang dipilih. Teori utilitas klasik mengasumsikan bahwa perusahaan yang rasional berusaha untuk memaksimalkan utilitas harapan mereka dan memilih diantara alternatif investasi mereka yang sesuai. Secara matematis, hal ini dinyatakan bahwa $A$ lebih disukai daripada $B$ jika dan hanya jika memenuhi terminal wealth $E_{w}\left[U\left(w_{A}\right)\right]-E_{w}\left[U\left(w_{B}\right)\right] \geq 0$ dengan sekurang-kurangnya satu ketidaksamaan pasti $U\left(w_{A}\right)-U\left(w_{B}\right) \geq 0$ 
Fitur matematika fungsi utilitas $U$ menggambarkan risiko/ motivasi reward suatu perusahaan. Fiturfitur yang sama juga menentukan apakah karakteristik stochastic distribusi terminal wealth harus dimiliki jika salah satu alternatif yang akan lebih dipilih daripada yang lain (Heyer, 2001).

1. Increasing Wealth Preference (Meningkatkan Preferensi Kekayaan)

Fitur ini menangkap lebih banyak kekayaan lebih baik, filosofi perilaku perusahaan dan umumnya dianggap sebagai fitur universal fungsi utilitas. Untuk kekayaan yang lebih besar lebih disukai, fungsi utilitas harus monoton meningkat. Secara matematis ini dinyatakan bahwa sebuah fungsi utilitas memiliki peningkatan preferensi kekayaan jika dan hanya jika $U^{\prime} \geq 0$ untuk semua w sekurang-kurangnya satu ketidaksamaan pasti (Heyer, 2001).

2. Risk Aversion

Fitur ini adalah bagian dari peningkatan preferensi kekayaan, perusahaan mungkin memiliki peningkatan preferensi kekayaan dengan atau tanpa menunjukkan penghindaran risiko, dan juga umumnya dianggap sebagai fitur universal fungsi utilitas. Secara matematis ini dinyatakan bahwa sebuah fungsi utilitas memiliki risk aversion jika dan hanya jika memenuhi kondisi untuk meningkatkan preferensi kekayaan dan $U^{\prime \prime}(w) \leq 0$ untuk semua $w$ sekurang-kurangnya satu ketidaksamaan pasti.

Hal ini tidak intuitif jelas, dalam definisi matematika ini risk aversion adalah ekuivalen dengan definisi perilaku yang diberikan di atas. Untuk membuat hubungan ini lebih jelas maka harus disadari bahwa pada increasing wealth preference mendefinisikan fungsi cekung dan menerapkan ketidaksamaan Jensen, sehingga:

$$
E_{w}[U(w)] \leq U\left(E_{w}[w]\right)
$$

Dalam risk aversion, utilitas yang diharapkan dari investasi yang berisiko kurang dari utilitas dari hasil yang diharapkan, karena proposisi perusahaan memiliki hukum utilitas investasi untuk kemungkinan hasil yang tidak menguntungkan. Jika ditulis kembali ketidaksamaan Jensen dengan ketidaksamaan sempurna, maka dapat ditunjukkan bahwa:

$$
E_{w}[U(w)]=U\left(E_{w}[w]-\pi\right)
$$

Hal ini menunjukkan bahwa perusahaan bersikap acuh tak acuh antara return pada suatu investasi yang berisiko atau lebih rendah, risiko bebas kekayaan sama dengan $E_{w}[w]-\pi$ dimana $\pi$ adalah premium bahwa perusahaan bersedia membayar untuk menghilangkan risiko (Heyer, 2001).

\section{Skewness Preference (Ruin Aversion)}

Fitur ini disajikan klasik sebagai kesediaan individu untuk bermain lotre: menerima kecil, kehilangan hampir pasti dalam pertukaran untuk kemungkinan tipis keuntungan besar. Perhatian suatu perusahaan bagaimanapun adalah dengan situasi sebaliknya, keengganan untuk menerima kecil, keuntungan hampir pasti dalam pertukaran untuk kemungkinan tipis kegagalan. Ini adalah bagian dari risk aversion, sebuah perusahaan mungkin memiliki risk aversion dengan atau tanpa menunjukkan ruin aversion. Secara matematis ini dinyatakan bahwa sebuah fungsi utilitas memiliki ruin aversion jika dan hanya jika memenuhi kondisi untuk risk aversion dan $U^{\prime \prime \prime}(w) \geq 0$ untuk semua $w$ sekurang-kurangnya satu ketidaksamaan pasti.

Seperti risk aversion, hal ini tidak intuitif jelas, bahwa definisi matematika dan perilaku ruin aversion konsisten. Jika mengambil ekspansi deret Taylor dari fungsi utilitas tentang $E_{w}[w]$, dan mengambil harapan respek untuk $w$, maka dapat diperoleh:

$$
\begin{aligned}
U(w)= & U\left(E_{w}[w]\right)+U^{\prime}\left(E_{w}[w]\right) \cdot\left(w-E_{w}[w]\right)+\frac{U^{\prime \prime}\left(E_{w}[w]\right)}{2 !} \cdot\left(w-E_{w}[w]\right)^{2} \\
& +\frac{U^{\prime \prime}\left(E_{w}[w]\right)}{3 !} \cdot\left(w-E_{w}[w]\right)^{3}
\end{aligned}
$$




$$
E_{w}[U(w)]=U\left(E_{w}[w]\right)+\frac{U^{\prime \prime}\left(E_{w}[w]\right)}{2 !} \cdot \sigma_{w}^{2}+\frac{U^{\prime \prime}\left(E_{w}[w]\right)}{3 !} \cdot \mu_{3}
$$

Dari hal di atas terlihat bahwa setiap fitur investasi yang meningkatkan skewness positif $\mu_{3}$ (atau mengurangi skewness negatif) bertindak untuk meningkatkan utilitas yang diharapkan (Heyer, 2001).

\section{Stochasic Dominance}

Stochastic dominance mula-mula berkembang di bidang keuangan yaitu dalam pengambilan keputusan keuangan menggunakan fungsi utilitas, salah satunya adalah untuk mengatasi masalah mengenai pemilihan dan evaluasi dari investasi saham maupun portofolio, tanpa harus menggunakan distribusi normal untuk tingkat keuntungan. Dalam teori pengambilan keputusan menghadapi ketidakpastian (uncertainty), suatu perusahaan biasanya bertujuan untuk memaksimumkan nilai harapan dari fungsi utilitas (expected utility), suatu fungsi tujuan tertentu yang ditetapkan oleh perusahaan berdasarkan pilihan kondisi yang ada. Andaikan ada dua pilihan kondisi, A dan B, maka kondisi A akan lebih disukai dibandingkan kondisi B jika dan hanya jika nilai harapan utilitas dari A lebih tinggi atau sama dibandingkan nilai harapan dari utilitas B. Dalam bentuk matematis, jika $W$ adalah variabel random non negatif dengan fungsi densitas $f(w)$ dan fungsi distribusi $f(w)$ serta $U A(w)$ dan $U B(w)$ adalah fungsi utilitas A dan B, diasumsikan memiliki derivatif ke-s, maka kondisi A lebih disukai dari B jika dan hanya jika (Heyer, 2001):

$$
E\left[U_{A}(W)\right]=\int_{-\infty}^{+\infty} U_{A}(t) f(t) d \geq \int_{-\infty}^{+\infty} U_{B}(t) f(t) d=E\left[U_{B}(W)\right]
$$

dimana ini merupakan definisi umum dari stochastic dominance.

\section{Asumsi-Asumsi Stochastic Dominance}

Stochastic Dominance menggunakan tiga asumsi tentang perilaku para investor, yaitu first order stochastic dominance, second order stochastic dominance, dan third order stochastic dominance (Kjetsaa dan Kieff, 2003, p.2). Stochastic dominance orde ke-s didefinisikan berdasarkan karakteristik dari fungsi utilitas yang digunakan. Teori utilitas klasik mengasumsikan bahwa perusahaan yang rasional berusaha untuk memaksimalkan utilitas harapan dan memilih di antara alternatif investasi yang sesuai. Secara matematis, hal ini dinyatakan bahwa A lebih disukai daripada B jika dan hanya jika memenuhi terminal wealth

$$
E_{w}\left[U\left(w_{A}\right)\right]-E_{w}\left[U\left(w_{B}\right)\right] \geq 0
$$

dengan sekurang-kurangnya satu ketidakpastian $U\left(w_{A}\right)-U\left(w_{B}\right) \geq 0$.

Fitur matematika fungsi utilitas $U$ menggambarkan risiko/ motivasi reward suatu perusahaan. Fiturfitur yang sama juga menentukan apakah karakteristik stokastik distribusi terminal wealth harus dimiliki jika salah satu alternatif yang akan lebih dipilih daripada yang lain. Evaluasi karakteristik stokastik ini adalah dasar analisis stochastic dominance.

Ada beberapa karakteristik dari fungsi utilitas yang sering digunakan yaitu: Increasing Wealth Preference (monotonicity), concavity (risk aversion) dan ruin aversion (Heyer, 2001). Fungsi utilitas memiliki sifat Increasing Wealth Preference/ monotonicity artinya semakin tinggi tingkat utilitas semakin baik, secara matematis dinyatakan bahwa suatu fungsi utilitas memiliki sifat Increasing Wealth Preference (monotonicity) jika dan hanya jika $U^{\prime}(w) \geq 0$ untuk semua $w$.

Fungsi utilitas memiliki sifat concavity (risk aversion), fitur ini adalah bagian dari peningkatan preferensi kekayaan, perusahaan mungkin memiliki peningkatan preferensi kekayaan dengan atau tanpa menunjukkan penghindaran risiko. Secara matematis dinyatakan bahwa suatu fungsi utilitas memiliki sifat concavity (risk aversion) jika dan hanya jika memiliki sifat Increasing Wealth Preference dan $U^{\prime \prime}(w) \leq 0$ untuk semua $w$.

Fungsi utilitas skewness preference (ruin aversion), fitur ini adalah bagian dari risk aversion, sebuah perusahaan mungkin memiliki risk aversion dengan atau tanpa menunjukkan ruin aversion. Secara 
matematis dinyatakan bahwa suatu fungsi utilitas memiliki ruin aversion jika dan hanya jika memenuhi kondisi untuk risk aversion dan $U^{\prime \prime}(w) \geq 0$ untuk semua $w$.

First order stochastic dominance diturunkan dari sifat fungsi utilitas Increasing Wealth Preference (monotonicity), second order stochastic dominance diturunkan dari sifat concavity (risk aversion) dan third order stochastic dominance diturunkan dari sifat ruin aversion (Heyer, 2001).

1. First-Order Stochastic Dominance

Dengan definisi preferensi yang diberikan dalam persamaan (2) dan kendala yang paling umum pada fungsi utilitas yang diberikan dalam Increasing Wealth Preference, persamaan (2) dapat diintegralkan sebagai berikut:

$$
\begin{aligned}
& E_{w}\left[U\left(w_{A}\right)\right]-E_{w}\left[U\left(w_{B}\right)\right] \geq 0 \\
& \int_{-\infty}^{\infty} U(t) f_{A}(t) d-\int_{-\infty}^{\infty} U(t) f_{B}(t) d \geq 0 \\
& \int_{-\infty}^{\infty} U(t) \cdot\left[f_{A}(t)-f_{B}(t)\right] d \geq 0 \\
&\left.U(t) \cdot\left[f_{A}(t)-f_{B}(t)\right]\right|_{-\infty} ^{\infty}-\int_{-\infty}^{\infty}\left[f_{A}(t)-f_{B}(t)\right] \cdot U^{\prime}(t) d \geq 0
\end{aligned}
$$

Diketahui bahwa pada Increasing Wealth Preference $U^{\prime}(w) \geq 0$, supaya persamaan (3) menjadi benar untuk semua fungsi utilitas dengan peningkatan preferensi kekayaan, maka harus memiliki: $A$ adalah uniformly preferred untuk $B$ pada Increasing Wealth Preference ( $A$ mendominasi $B$ pada First-Order Stochastic Dominance) jika dan hanya jika $\left[F_{B}(w)-F_{A}(w)\right] \geq 0$ untuk semua $w$ dengan ketidaksamaan pasti untuk sekurang-kurangnya satu nilai w. (4-4)

2. Second-Order Stochastic Dominance

Dalam hal ini akan digunakan suatu penguat kendala fungsi utilitas (risk aversion) untuk mengembangkan kriteria seleksi investasi. Dengan definisi preferensi yang diberikan dalam persamaan (2) dan definisi risk aversion, persamaan (2) dapat diintegralkan dua kali untuk menghasilkan:

$$
U^{\prime}(\infty) \cdot \int_{-\infty}^{\infty}\left[F_{B}(t)-F_{A}(t)\right] d-\int_{-\infty}^{\infty} U^{\prime \prime}(t) \int_{-\infty}^{t}\left[F_{B}(u)-F_{A}(u)\right] d \quad \geq 0
$$

Karena risk aversion adalah bagian dari peningkatan preferensi kekayaan (Increasing Wealth Preference) maka $U^{\prime}(\infty) \cdot \int_{-\infty}^{\infty}\left[F_{B}(t)-F_{A}(t)\right] d$ adalah positif. Pada definisi risk aversion diketahui bahwa $U^{\prime \prime}(w) \leq 0$, sehingga agar persamaan (4) menjadi benar untuk semua fungsi utilitas dengan risk aversion, maka harus memiliki:

$A$ adalah uniformly preferred untuk $B$ pada risk aversion ( $A$ mendominasi $B$ pada second order stochastic dominance) jika dan hanya jika $\int_{-\infty}^{w}\left[F_{B}(u)-F_{A}(u)\right] d \geq 0$ untuk semua $w$ dengan ketidaksamaan pasti untuk sekurang-kurangnya satu nilai w. (4-6)

3. Third-Order Stochastic Dominance

Dengan menggunakan definisi preferensi yang diberikan dalam persamaan (2) dan definisi ruin aversion, persamaan (2) dapat diintegralkan tiga kali untuk menghasilkan:

$$
\begin{gathered}
\left.U^{\prime}(\infty) \cdot \int_{-\infty}^{\infty}\left[F_{B}(t)-F_{A}(t)\right] d-U^{\prime \prime}(x) \int_{-\infty}^{x} \int_{-\infty}^{t}\left[F_{B}(u)-F_{A}(u)\right] d\right]_{-\infty}^{\infty} \\
\quad+\int_{-\infty}^{\infty} U^{\prime \prime}(w) \int_{-\infty}^{w} \int_{-\infty}^{t}\left[F_{B}(u)-F_{A}(u)\right] d \quad \geq 0
\end{gathered}
$$

Karena risk aversion adalah bagian ruin aversion maka 


$$
U^{\prime}(\infty) \cdot \int_{-\infty}^{\infty}\left[F_{B}(t)-F_{A}(t)\right] d-\left.U^{\prime \prime}(x) \int_{-\infty}^{x} \int_{-\infty}^{t}\left[F_{B}(u)-F_{A}(u)\right] d \quad\right|_{-\infty} ^{\infty}
$$

adalah positif. Pada definisi ruin aversion diketahui bahwa $U^{\prime \prime}(w) \geq 0$, agar persamaan menjadi benar untuk semua fungsi utilitas dengan ruin aversion, maka harus memiliki:

$A$ adalah uniformly preferred untuk $B$ pada ruin aversion (A mendominasi $B$ pada third order stochastic dominance) jika dan hanya jika $\int_{-\infty}^{x} \int_{-\infty}^{t}\left[F_{B}(u)-F_{A}(u)\right] d \geq 0$ untuk semua w dengan ketidaksamaan pasti untuk sekurang-kurangnya satu nilai $w$.

\section{Analisis Portofolio Menggunakan Metode Stochastic Dominance}

Aturan stochastic dominance adalah suatu pendekatan teoritis yang lain dalam masalah pemilihan portofolio. Stochastic Dominance merupakan suatu teknik untuk memilih investasi yang berisiko tanpa harus menggunakan distribusi normal untuk tingkat keuntungan.

Tingkat keuntungan (return) dari saham individual merupakan tingkat pengembalian yang diperoleh dari investasi saham. Return saham diukur dari selisih harga penutupan dan pembukaan terhadap harga pembukaan dari saham:

$$
R_{i}=\frac{P_{t}-P_{t-1}}{P_{t-1}}
$$

Keuntungan yang diharapkan (expected return) saham merupakan tingkat keuntungan atau pengembalian yang diharapkan dari investasi saham. Expected return saham diukur dari total return saham terhadap total periode waktu:

$$
E\left(R_{p}\right)=X_{A} E\left(R_{A}\right)+X_{B} E\left(R_{B}\right)
$$

Probabilitas merupakan kemungkinan atau peluang terjadinya suatu kejadian. Probabilitas diukur dengan membagi jumlah kejadian yang diinginkan terhadap keseluruhan kejadian yang mungkin terjadi.

$$
P(E)=\frac{X}{N}
$$

Kriteria metode stochastic dominance dan preferensi investor adalah sebagai berikut:

1) First order stochastic dominance adalah probabilitas kumulatif dari setiap saham. Saham A lebih disukai daripada saham $B$, dimana saham A dikatakan mendominasi saham B (A dominan B) $\left[F_{B}(w)-F_{A}(w)\right] \geq 0$, jika saham A tidak pernah mempunyai probabilitas kumulatif untuk memperoleh return tertentu atau kurang, yang lebih besar dari B untuk setiap kemungkinan nilai return. Dalam hal ini investor menyukai banyak daripada sedikit $U^{\prime}(w) \geq 0$.

2) Second order stochastic dominance adalah penjumlahan probabilitas kumulatif dari probabilitas kumulatif. Saham A lebih disukai daripada saham B (saham dominan A) $\int_{-\propto}^{w}\left[F_{B}(u)-F_{A}(u)\right] d \geq$ 0 , jika saham A tidak pernah mempunyai penjumlahan probabilitas kumulatif untuk memperoleh return tertentu atau kurang, yang lebih besar dari B untuk setiap kemungkinan nilai return. Dalam hal ini investor bersikap tidak menyukai risiko (risk averse) $U^{\prime \prime}(w) \leq 0$.

3) Third order stochastic dominance adalah penjumlahan probabilitas-probabilitas kumulatif dari penjumlahan probabilitas kumulatif. Saham A lebih disukai daripada saham B (saham dominan A) $\int_{-\infty}^{x} \int_{-\infty}^{t}\left[F_{B}(u)-F_{A}(u)\right] d \geq 0$, apabila saham A tidak pernah mempunyai penjumlahan probabilitas-probabilitas kumulatif untuk memperoleh return tertentu atau kurang, yang lebih besar dari B untuk setiap kemungkinan nilai return. Dalam hal ini investor bersikap ruin averse $U^{\prime \prime}(w) \geq$ 0 .

4) Saham tanpa dominasi adalah suatu keadaan dimana saham A maupun saham B tidak dapat diketahui mana yang lebih disukai (tanpa dominasi saham A maupun saham G), jika saham A 
maupun saham B pernah mempunyai probabilitas kumulatif untuk memperoleh return tertentu, yang lebih besar dari A maupun B untuk setiap kemungkinan nilai return. Dalam hal ini investor bersikap indifferent.

Probabilitas kumulatif diperoleh dari peluang-peluang hasil investasi A dan investasi B dalam urutan meningkat, dengan cara menggabungkan dan memperingkat return dari yang minimal sampai dengan return maksimal (secara short ascending) dari pasangan investasi A dan B, kemudian menghitung probabilitas setiap investasi A dengan investasi B. Adapun cara penghitungannya adalah menjumlahkan setiap probabilitas dari setiap return masing-masing investasi dalam urutan meningkat. Penjumlahan probabilitas-probabilitas kumulatif diperoleh dengan cara menjumlahkan setiap peluang masing-masing investasi A dan investasi B, dan penjumlahan probabilitas kumulatif dalam urutan meningkat (ascending).

\section{Portofolio Optimal Berdasarkan Metode Stochastic Dominance}

Pembentukan portofolio optimal menggunakan stochastic dominance berdasarkan saham-saham yang telah terseleksi melalui tahapan-tahapan, yaitu first order stochastic dominance, second order stochastic dominance, atau third order stochastic dominance.

Stochastic Dominance menggunakan tiga asumsi tentang perilaku para investor, yaitu first order stochastic dominance, second order stochastic dominance, dan third order stochastic dominance (Kjetsaa dan Kieff, 2003, p.2). First order stochastic dominance menyatakan bahwa pemodal lebih menyukai yang banyak daripada yang sedikit, second order stochastic dominance menyatakan bahwa pemodal bersikap risk averse atau tidak menyukai risiko dan third order stochastic dominance menyatakan bahwa pemodal mempunyai sikap ruin averse, asumsi yang ketiga ini berarti bahwa dengan meningkatnya kekayaan para pemodal, mereka akan menginvestasikan yang lebih banyak pada kesempatan investasi yang berisiko. Asumsi-asumsi tersebut akan dipergunakan dan dijelaskan dalam contoh-contoh berikut ini (Husnan, 2009, p.146).

\section{Hasil dan Pembahasan}

Sampel pada penelitian ini diambil berdasarkan populasi saham Jakarta Islamic Index (JII) periode 1 Januari 2012 sampai dengan 31 Desember 2014. Saham-saham yang memiliki nilai mean return positif kemudian dipilih 9 saham secara random/acak yang akan dibentuk dalam analisis portofolio optimal.

Tabel 1 Saham Kandidat Portofolio Optimal.

\begin{tabular}{clc}
\hline No & Kode & Mean Return \\
\hline 1 & WIKA & 0,002687 \\
2 & MPPA & 0,001950 \\
3 & CTRA & 0,001520 \\
4 & ICBP & 0,001395 \\
5 & MNCN & 0,001233 \\
6 & JSMR & 0,000804 \\
7 & INDF & 0,000633 \\
8 & PGAS & 0,001046 \\
9 & SMGR & 0,000686 \\
\hline
\end{tabular}

\section{Pembentukan Portofolio Optimal}

1. Proses Stochastic Dominance antar Pasangan Saham Emiten

Pembentukan portofolio optimal menggunakan stochastic dominance melalui tahapan-tahapan, yaitu first order stochastic dominance, second order stochastic dominance, atau third order stochastic dominance. Sebagai contoh sistematis penghitungannya, berikut ini akan dilakukan proses dan 
analisis data dari saham MNCN (Media Nusantara Citra Tbk) dan JSMR (Jasa Marga (Persero) Tbk) menggunakan Microsoft Excel.

a. Menghitung Return Saham Individual

b. Menentukan Probabilitas untuk Setiap Saham

Probabilitas adalah suatau nilai untuk mengukur tingkat kemungkinan terjadinya suatu kejadian acak. Periode pengamatan dalam penelitian ini adalah 1 Januari 2012 sampai dengan 31 Desember 2014 atau 36 bulan, sehingga nilai probabilitas untuk setiap return saham adalah sebesar $1 / 36$ atau 0,028 .

c. Mengumpulkan Return dan Probabilitas dari Pasangan Saham

Seluruh return dan probabilitas dari masing-masing saham diurutkan dari yang minimal sampai yang maksimal (secara sort ascending), seperti pada tabel berikut:

\begin{tabular}{ccccc}
\hline No & $\begin{array}{c}\text { Return } \\
\text { MNCN }\end{array}$ & $\begin{array}{c}\text { Probabilitas } \\
\text { MNCN }\end{array}$ & $\begin{array}{c}\text { Return } \\
\text { JSMR }\end{array}$ & $\begin{array}{c}\text { Probabilitas } \\
\text { JSMR }\end{array}$ \\
\hline 1 & $-0,2277$ & 0,028 & $-0,1110$ & 0,028 \\
2 & $-0,1290$ & 0,028 & $-0,0713$ & 0,028 \\
3 & $-0,1245$ & 0,028 & $-0,0592$ & 0,028 \\
$\vdots$ & & & & \\
35 & 0,2106 & 0,028 & 0,0988 & 0,028 \\
36 & 0,2501 & 0,028 & 0,1421 & 0,028 \\
\hline
\end{tabular}

Selanjutnya adalah mengumpulkan nilai return dan nilai probabilitas dari pasangan saham.

Apabila terdapat nilai return yang sama pada masing-masing saham, maka nilai probabilitasnya dijumlahkan. Sebagai contoh pada saham MNCN memiliki nilai return 0,012 sebanyak dua kali dengan nilai probabilitas pada masing-masing return sebesar 0,028, maka nilai probabilitas dari kedua return tersebut dijumlahkan menjadi 0,056. Apabila terdapat nilai return yang sama pada kedua saham (pasangan saham), maka nilai probabilitasnya disejajarkan. Sebagai contoh pada saham MNCN memiliki nilai return $-0,0427$ dan JSMR juga memiliki nilai return $-0,0427$ dengan nilai probabilitas masing-masing saham sebesar 0,028 , maka penulisan nilai return dan nilai probabilitas dari pasangan saham tersebut disejajarkan.

d. First Order Stochastic Dominance dari Pasangan Saham

Tahapan first order stochastic dominance dilakukan dengan cara menghitung probabilitas kumulatif dari setiap return masing-masing saham emiten dalam urutan meningkat (ascending).

\begin{tabular}{ccccc}
\hline Return & $\begin{array}{c}\text { Prob, } \\
\text { MNCN }\end{array}$ & $\begin{array}{c}\text { Prob, } \\
\text { JSMR }\end{array}$ & $\begin{array}{c}\text { Prob, } \\
\text { Kumulatif MNCN }\end{array}$ & $\begin{array}{c}\text { Prob, } \\
\text { Kumulatif JSMR }\end{array}$ \\
\hline$-0,2277$ & 0,028 & 0 & 0,028 & 0 \\
$-0,1290$ & 0,028 & 0 & 0,056 & 0 \\
$-0,1245$ & 0,028 & 0 & 0,083 & 0 \\
$-0,1147$ & 0,028 & 0 & 0,111 & 0 \\
$-0,1131$ & 0,028 & 0 & 0,139 & 0 \\
$-0,1110$ & 0 & 0,028 & 0,139 & 0,028 \\
$\vdots$ & & & & 1 \\
0,1801 & 0,028 & 0 & 0,917 & 1 \\
0,1957 & 0,028 & 0 & 0,944 & 1 \\
0,2106 & 0,028 & 0 & 0,972 & 1 \\
0,2501 & 0,028 & 0 & 1 & \\
\hline
\end{tabular}

Berdasarkan tabel di atas dapat diketahui bahwa pada return -0,1290 saham MNCN memiliki probabilitas kumulatif sebesar 0,028 , lebih besar dari probabilitas kumulatif saham JSMR yaitu sebesar 0 . Pada return 0,0093 saham MNCN memiliki probabilitas kumulatif sebesar 0,417, lebih 
kecil dari probabilitas kumulatif saham JSMR sebesar 0,444. Sehingga dari hal tersebut saham MNCN dan JSMR belum diketahui hasil dominasinya dari first order stochastic dominance. Karena pada first order stochastic dominance saham MNCN dan JSMR belum diketahui hasil dominasinya, maka selanjutnya adalah menghitung second order stochastic dominance.

e. Second Order Stochastic Dominance dari Pasangan Saham

Tahapan second order stochastic dominance dilakukan dengan cara menjumlahkan setiap probabilitas dari setiap return saham emiten individual pada probabilitas kumulatif dalam urutan meningkat (ascending).

\begin{tabular}{ccccccc}
\hline \multirow{2}{*}{ Return } & \multicolumn{2}{c}{ Probabilitas } & Probabilitas & Kumulatif & \multicolumn{2}{c}{$\begin{array}{c}\text { Penjumlahan } \\
\text { Probabilitas }\end{array}$} \\
\cline { 2 - 7 } & MNCN & JSMR & MNCN & JSMR & MNCN & JSMR \\
\hline$-0,2277$ & 0,028 & 0 & 0,028 & 0 & 0,028 & 0 \\
$-0,1290$ & 0,028 & 0 & 0,056 & 0 & 0,083 & 0 \\
$-0,1245$ & 0,028 & 0 & 0,083 & 0 & 0,167 & 0 \\
$-0,1147$ & 0,028 & 0 & 0,111 & 0 & 0,278 & 0 \\
$-0,1131$ & 0,028 & 0 & 0,139 & 0 & 0,417 & 0 \\
$-0,1110$ & 0 & 0,028 & 0,139 & 0,028 & 0,556 & 0,028 \\
$\vdots$ & & & & & & \\
0,1801 & 0,028 & 0 & 0,917 & 1 & 31,889 & 33,917 \\
0,1957 & 0,028 & 0 & 0,944 & 1 & 32,833 & 34,917 \\
0,2106 & 0,028 & 0 & 0,972 & 1 & 33,806 & 35,917 \\
0,2501 & 0,028 & 0 & 1 & 1 & 34,806 & 36,917 \\
\hline
\end{tabular}

Tabel di atas menunjukkan bahwa pada return -0,1290 saham MNCN memiliki penjumlahan probabilitas kumulatif sebesar 0,083, lebih besar dari penjumlahan probabilitas kumulatif saham JSMR yaitu sebesar 0. Pada return 0,0791 saham MNCN memiliki penjumlahan probabilitas kumulatif sebesar 23,028, lebih kecil dari penjumlahan probabilitas kumulatif saham JSMR sebesar 23,222. Sehingga dari hal tersebut saham MNCN dan JSMR belum diketahui hasil dominasinya dari second order stochastic dominance. Karena pada second order stochastic dominance saham MNCN dan JSMR belum diketahui hasil dominasinya, maka selanjutnya adalah menghitung third order stochastic dominance.

f. Third Order Stochastic Dominance dari Pasangan Saham

Tahapan third order stochastic dominance dilakukan dengan cara menjumlahkan setiap probabilitas dari setiap return saham emiten individual pada penjumlahan probabilitas kumulatif dalam urutan meningkat (ascending).

\begin{tabular}{|c|c|c|c|c|c|c|c|c|}
\hline \multirow{2}{*}{ Return } & \multicolumn{2}{|c|}{ Probabilitas } & \multicolumn{2}{|c|}{$\begin{array}{c}\text { Probabilitas } \\
\text { Kumulatif }\end{array}$} & \multicolumn{2}{|c|}{$\begin{array}{c}\text { Penjumlahan } \\
\text { Probabilitas Kumulatif }\end{array}$} & \multicolumn{2}{|c|}{ Penjumlahan Probabilitas } \\
\hline & MNCN & JSMR & MNCN & JSMR & MNCN & JSMR & $\begin{array}{c}\text { Prob, Kum } \\
\text { MNCN }\end{array}$ & $\begin{array}{c}\text { Prob, Kum } \\
\text { JSMR }\end{array}$ \\
\hline$-0,2277$ & 0,028 & 0 & 0,028 & 0 & 0,028 & 0 & 0,028 & 0 \\
\hline$-0,129$ & 0,028 & 0 & 0,056 & 0 & 0,083 & 0 & 0,111 & 0 \\
\hline$-0,1245$ & 0,028 & 0 & 0,083 & 0 & 0,167 & 0 & 0,278 & 0 \\
\hline$-0,1147$ & 0,028 & 0 & 0,111 & 0 & 0,278 & 0 & 0,556 & 0 \\
\hline$-0,1131$ & 0,028 & 0 & 0,139 & 0 & 0,417 & 0 & 0,972 & 0 \\
\hline$-0,111$ & 0 & 0,028 & 0,139 & 0,028 & 0,556 & 0,028 & 1,528 & 0,028 \\
\hline$\vdots$ & & & & & & & & \\
\hline 0,1801 & 0,028 & 0 & 0,917 & 1 & 31,889 & 33,917 & 809,222 & 706,944 \\
\hline 0,1957 & 0,028 & 0 & 0,944 & 1 & 32,833 & 34,917 & 842,056 & 741,861 \\
\hline
\end{tabular}




\begin{tabular}{ccccccccc}
0,2106 & 0,028 & 0 & 0,972 & 1 & 33,806 & 35,917 & 875,861 & 777,778 \\
0,2501 & 0,028 & 0 & 1 & 1 & 34,806 & 36,917 & 910,667 & 814,694 \\
\hline
\end{tabular}

Tabel di atas menunjukkan bahwa penjumlahan probabilitas-probabilitas kumulatif saham JSMR tidak pernah lebih besar dari penjumlahan probabilitas-probabilitas kumulatif saham MNCN, sehingga pada third order stochastic dominance dapat diketahui bahwa saham JSMR lebih dominan daripada saham MNCN, dalam hal ini pemodal diasumsikan bersikap ruin averse, asumsi ini berarti bahwa dengan meningkatnya kekayaan para pemodal, mereka akan menginvestasikan yang lebih banyak pada kesempatan investasi yang berisiko.

g. Pencatatan Hasil Dominasi Secara Stokastik antar Pasangan Saham Emiten

Langkah selanjutnya adalah melakukan pencatatan hasil dari dominasi secara stokastik pasangan antar saham emiten (pada first order stochastic dominance, second order stochastic dominance atau third order stochastic dominance) dan hasil tidak dominan secara stokastik pasangan antar saham emiten. Hasil dominasi seluruh sampel penelitian (baik dominan maupun tidak dominan) dapat dilihat pada tabel berikut ini:

\begin{tabular}{|l|l|c|c|c|c|c|c|c|c|c|c|}
\hline \multicolumn{2}{|l|}{} & & 1 & $\mathbf{2}$ & $\mathbf{3}$ & $\mathbf{4}$ & $\mathbf{5}$ & $\mathbf{6}$ & $\mathbf{7}$ & $\mathbf{8}$ & $\mathbf{9}$ \\
\hline & A & B & C & D & E & F & G & H & I \\
\hline $\mathbf{1}$ & Wijaya Karya (Persero) Tbk. & A & & & & & & & & & \\
\hline $\mathbf{2}$ & Matahari Putra Prima Tbk. & B & A & & & & & & & & \\
\hline $\mathbf{3}$ & Ciputra Development Tbk. & C & A & & & & & & & & \\
\hline $\mathbf{4}$ & Indofood CBP Sukses Makmur Tbk. & D & & D & & & & & & \\
\hline $\mathbf{5}$ & Media Nusantara Citra Tbk. & E & A & & D & & & & & \\
\hline $\mathbf{6}$ & Jasa Marga (Persero) Tbk. & F & & F & & & F & & & & \\
\hline $\mathbf{7}$ & Indofood Sukses Makmur Tbk. & G & & & & G & F & & & \\
\hline $\mathbf{8}$ & Perusahaan Gas Negara (Persero) Tbk. & H & H & H & & H & J & & & \\
\hline $\mathbf{9}$ & Semen Indonesia (Persero) Tbk. & I & & & D & I & F & & H & \\
\hline
\end{tabular}

Berikut ini adalah penjelasan berdasarkan tabel di atas:

1. Diagonal (misalnya $A$ dan A) tidak dihitung sebagai pasangan saham.

2. Sel warna kuning menunjukkan bahwa saham dominan pada second order stochastic dominance, dalam hal ini pemodal diasumsikan bersikap risk averse atau tidak menyukai risiko. Sebagai contoh pada pasangan saham A (Wijaya Karya (Persero) Tbk) dan saham C (Ciputra Development Tbk), menunjukkan saham A (Wijaya Karya (Persero) Tbk) dominan pada second order stochastic dominance.

3. Sel warna hijau menunjukkan bahwa saham dominan pada third order stochastic dominance, dalam hal ini pemodal diasumsikan bersikap ruin averse, asumsi ini berarti bahwa dengan meningkatnya kekayaan para pemodal, mereka akan menginvestasikan yang lebih banyak pada kesempatan investasi yang berisiko. Sebagai contoh pasangan pada saham A (Wijaya Karya (Persero) Tbk) dan saham B (Matahari Putra Prima Tbk), menunjukkan saham A (Wijaya Karya (Persero) Tbk) dominan pada third order stochastic dominance.

4. Sel warna abu-abu menunjukkan tidak ada dominasi diantara kedua saham (pasangan saham). Sebagai contoh pada pasangan saham A (Wijaya Karya (Persero) Tbk) dan saham D (Indofood CBP Sukses Makmur Tbk), menunjukkan tidak ada dominasi diantara kedua saham (pasangan saham).

h. Menentukan Peringkat Saham Emiten Berdasarkan Jumlah Dominasi

Hasil dominasi secara stokastik pada tabel 5.10 digunakan untuk menyusun peringkat saham emiten berdasarkan jumlah dominasi. Peringkat saham berdasarkan jumlah dominasi dapat dilihat pada tabel berikut: 


\begin{tabular}{clc}
\hline $\begin{array}{c}\text { Peringkat } \\
\text { Saham }\end{array}$ & Saham & Dominasi \\
\hline 1 & Jasa Marga (Persero) Tbk. & 4 \\
2 & Perusahaan Gas Negara (Persero) Tbk. & 4 \\
3 & Wijaya Karya (Persero) Tbk. & 3 \\
4 & Indofood CBP Sukses Makmur Tbk. & 3 \\
5 & Indofood Sukses Makmur Tbk. & 1 \\
6 & Semen Indonesia (Persero) Tbk. & 1 \\
7 & Ciputra Development Tbk. & 0 \\
8 & Matahari Putra Prima Tbk. & 0 \\
9 & Media Nusantara Citra Tbk. & 0 \\
\hline
\end{tabular}

Berdasarkan jumlah hasil dominasi di atas dapat diketahui bahwa terdapat 6 saham yang masuk dalam portofolio optimal dengan analisis stochastic dominance, diantaranya adalah saham Jasa Marga (Persero) Tbk, saham Perusahaan Gas Negara (Persero) Tbk, saham Wijaya Karya (Persero) Tbk, saham Indofood CBP Sukses Makmur Tbk, saham Indofood Sukses Makmur Tbk dan saham Semen Indonesia (Persero) Tbk.

2. Menentukan Proporsi Masing-masing Saham Emiten

Setelah sekuritas yang membentuk portofolio optimal ditentukan, maka selanjutnya adalah menghitung besar proporsi masing-masing saham dalam portofolio optimal. Berikut ini adalah hasil dan perhitungan proporsi masing-masing saham:

\begin{tabular}{clcc}
\hline No & Saham & Perhitungan & $W_{i}$ \\
\hline 1 & Jasa Marga (Persero) Tbk. & $4 / 16 \times 100 \%$ & $25 \%$ \\
2 & Perusahaan Gas Negara (Persero) Tbk. & $4 / 16 \times 100 \%$ & $25 \%$ \\
3 & Wijaya Karya (Persero) Tbk. & $3 / 16 \times 100 \%$ & $18,75 \%$ \\
4 & Indofood CBP Sukses Makmur Tbk. & $3 / 16 \times 100 \%$ & $18,75 \%$ \\
5 & Indofood Sukses Makmur Tbk. & $1 / 16 \times 100 \%$ & $6,25 \%$ \\
6 & Semen Indonesia (Persero) Tbk. & $1 / 16 \times 100 \%$ & $6,25 \%$ \\
\hline
\end{tabular}

3. Menentukan Return Ekspektasi Portofolio

Berdasarkan proporsi yang diperoleh maka didapatkan nilai return ekspektasi portofolio $E(R p)$ sebagai berikut:

\begin{tabular}{clccc}
\hline No & Kode Saham & $W_{i}$ & $E(R i)$ & $E(R p)$ \\
\hline 1 & JSMR & 0,25 & 0,0175 & 0,004375 \\
2 & PGAS & 0,25 & 0,0227 & 0,005675 \\
3 & WIKA & 0,1875 & 0,0583 & 0,010931 \\
4 & ICBP & 0,1875 & 0,0303 & 0,005681 \\
5 & INDF & 0,0625 & 0,0137 & 0,000856 \\
6 & SMGR & 0,0625 & 0,0149 & 0,000931 \\
\hline \multicolumn{5}{c}{ Total } \\
\hline
\end{tabular}




\section{Kesimpulan}

Penelitian ini menggunakan 9 saham dalam pembentukan portofolio optimal, tetapi hanya terdapat 6 saham yang membentuk portofolio optimal. Saham-saham tersebut adalah saham JSMR, PGAS, WIKA, ICBP, INDF dan SMGR. Proporsi tertinggi terdapat pada saham JSMR dan saham PGAS yaitu sebesar $25 \%$. Proporsi saham WIKA dan saham ICBP adalah sebesar 18,75\%. Sedangkan proporsi terendah terdapat pada saham INDF dan saham SMGR yaitu sebesar 6,25\%. Tingkat pengembalian yang diharapkan dalam portofolio optimal $E(R p)$ berdasarkan stochastic dominance adalah 2,845\%.

\section{Referensi}

[1] Arifin, A. 2007. Teori Keuangan dan Pasar Modal. Yogyakarta: EKONISIA FE UII.

[2] Bain, L.J. dan M. Engelhardt. 1992. Introduction to Probability and Mathematical Statistic 2nd. Ed. Belmont, CA: Duxbury Press.

[3] Darmadji, Tjiptono dan Hendy M. Fakhruddin. 2001. Pasar Modal di Indonesia. Jakarta: Salemba.

[4] Fahmi, I. dan Yovi L. H. 2011. Teori Portofolio dan Analisis Investasi. Bandung: Alfabeta.

[5] Halim, A. 2003. Analisis Investasi. Jakarta: Salemba Empat.

[6] Haming, M. 2010. Studi Kelayakan Investasi. Jakarta: PT. Bumi Aksara.

[7] Herryanto, Nar dan Tuti Gantini. 2009. Pengantar Statistika Matematika, Bandung: Yrama Widya.

[8] Heyer, D. D. 2001. Stochastic Dominance: A Tool for Evaluating Reinsurance Alternatives. CAS (Casualty Actuarial Society) Forum.

[9] Husnan, Suad. 2009. Dasar-Dasar Teori Portofolio dan Analisis Sekuritas Edisi Keempat. Yogyakarta: UPP STIM YKPN.

[10] Jogiyanto, Dr. 2003. Teori Portofolio dan Analisis Investasi Edisi Ketiga. Yogyakarta: BPFE.

[11] Kjetsaa, Richard and Maureen Kieff. 2003. Stochastic Dominance Analysis of Equity Mutual Fund Performance. Journal of American Business Review, Vol. 21, No. 1, 1-8.

[12] Koetin, E.A. 1993. Analisis Pasar Modal. Jakarta: Pustaka Sinar Harapan.

[13] Post, Thierry. 2003. Empirical Tests for Stochastic Dominance Efficiency. Journal of Finance, Vol. 58, No. 5, 19051931.

[14] Qudratullah, M.F., Dkk. 2009. Pengantar Statistik Matematika. Yogyakarta: SUKA Press UIN Sunan Kalijaga.

[15] Suhartono, dan Fadlillah Q. 2009. Portofolio Investasi dan Bursa Efek. Yogyakarta: UPP STIM YKPN.

[16] Supranto, J. 1992. Statistik Pasar Modal. Jakarta: Rineka Cipta.

[17] Tandelilin, E. 2001. Analisis Investasi dan Manajemen Portofolio. Yogyakarta: BPFE. 